vided that it retained a slight odour of the essence. 6. The essences that developed the largest quantity of ozone were those of cherry laurel, palmarosa, cloves, lavender, mint, juniper, lemons, fennel, and bergamot; those that gave it in less quantity were anise, nutmeg, cajeput, and thyme. 7. Camphor, as an ozonogenic agent, is inferior to all the above-named essences. 8. Eau de Cologne, honey water, and other perfumes, or aromatic tinctures, develop a proportionate quantity of ozone when they are exposed to the direct rays of the sun. 9. The flowers of the narcissus, hyacinth, mignonette, heliotrope, lily of the valley, $\& c$. , develop ozone in closed vessels. Flowers destitute of perfume do not develop it, and those which have but slight perfume develop it only in small quantities. As a corollary from these facts the professor recommended the use of flowers in marshy districts and in places infected with animal emanations, as the powerful oxidising influence of ozone may destroy them. The inhabitants of such regions should surround their houses with beds of the most odorous flowers.

THE fourth part of the "Researches undertaken in the Physiological Laboratory of Wurzburg," edited by Dr. Richard Gscheidlen, has been published. It contains a kindly notice of the life of Albert von Bezold, so untimely snatched away by death; a most profound investigation on nerve and muscle electricity, an abstract of which, we fear, would be unintelligible to our readers, by Worm-Muiller, of Christiania ; an essay on the Calabar bean, by the editor, and some remarks on the movements of the Iris, by Dr. Engelhardt. In this last it is shown that atropine paralyses the extremities of the third nerve, whilst Calabar bean acts as an irritant upon them, and he holds that there is a ganglionic nervous centre or organ imbedded in the iris, and intercalated between the fibres of the third and the sphincter which acts as an inhibitory centre on the sympathetic.

\section{PRIZE MEDALS OF THE ROYAL GEOGRAPHICAL SOCIETY}

THE Royal Geographical Society of London having taken into consideration the fact that a knowledge of geographical facts, and still more a knowledge of the science of geography, is not so common among educated persons as it ought to be, determined, about two years ago, to offer prizes in the shape of gold and bronze medals, to be competed for by boys from certain selected public schools. The principle which governed the choice of the schools, was the number of boys who were receiving education therein; no school having less than 200 boys being chosen for the competition.

An effort was made, at the time that the matter was under discussion, to get girls admitted as candidates. It was, however, objected that there were no public schools for girls which could be invited to compete, and it was also said that it might be well to see how the experiment would work with boys betore inviting girls to the competition.

These questions being settled, the next thing to arrange was the manner in which the examinations should be conducted. It was obvious that to bring a number of boys from the various schools scattered all over the country to London, would be practically impossible; and it was equally obvious that some process of selection would have to take place in the schools themselves, so that the best boys only should have their papers sent to the examiners appointed by the Council of the Royal Geographical Society. It was therefore determined that the subjects of examination should be divided into Political Geography and Physical Geography, and that no candidate should be pernitted to be examined in both subjects at the same time. Moreover, not more than four candidates in each subject were allowed to take the papers; these four, of course, having been selected by the masters of the various schools from among those most likely to pass. The Council of the Geographical Society could not undertake to direct any preliminary examination-ithat had to rest entirely with the authorities of the various schools.

It was ultimately determined that the exarnination should take place by means of papers of questions, which should be seint in sealed packets to the Head Masters of the selected schools; and that these papers should be given out and worked simuitaneousis at all the schools. The superintendence of the examinations was to be done by a master of each school, who was to be present during the whole time the paper was worked. In order to ensure, as far as possible, the strict fulfilment of the conditions under which the examination was to take place, a declaration was required to be signed by all the masters who were present while the work was going on. This declaration set forth that the candidates worked the papers without assistance, and that there were no globes or maps in the room where they were written. It also declared that the specified masters were present during the whole of the time.

Thirty-seven schools, containing in the aggregate about 12,700 boys, were invited to compete at the first examination. These schools included the nine schools of the Royal Commission of 1864, and all others in England, Scotland, and Ireland which, according to the latest edition of the "Public Schools Calendar," contained not less than 200 boys.

Twenty-one of the invited schools sent candidates; no school being permitted to send more than eight boys, four candidates in the subject of Physical, and four in that of Political Geography. Many schools did not send the maximum number. In fact, four schools had only one candidate each; and out of the twenty-one schools, only four presented the highest number of candidates allowed. Last year forty-two schools were invited to take part in the examinations, but only nineteen sent candidates.

The papers set, both in Physical and Political Geography, bore a remarkable resemblance to each other, and in looking over the syllabus published by the Geological Society, it is impossible not to feel that the line between the two is very feeble, and, in some instances, indefinitely indicated. The special subject appointed for next year is North America.

The examiners appointed for the first year were the Rev. W. G. Clark, F.R.G.S., Public Orator of the University of Cambridge, for Political, and Mr. A. R. Wallace, F.R.G.S., for Physical Geography; and for the second year the Dean of Chester for Physical, and Mr. Wallace for Political Geography.

The successful candidates received their awards last year and this at the anniversary meetings of the Royal Geographical Society.

Rossall School and the Liverpool College have been very distinguished in the examinations. In the first year Rossall carried off both the gold and the bronze medals for Physical Geography ; and in the second year the bronze medal for Physical, and the gold medal for Political Geography, both fell to pupils of the same school. The Liverpool College gained the gold medal for Political Gecgraphy in the first year, and the gold for Physical, and bronze for Political, in the second year. Honourable mentions have also been gained by the pupils of various other schools.

A very remarkable fact, to be noticed as the result of these examinations, is that the schools which obtained the prizes are not those which the general public is accustomed to look upon as the leading schools of England; while Eton, Harrow, and Rugby are among those who have, as yet, sent no candidates at all. This is the more noticeable as, to Englishmen, the travellers of the world, and the subjects of a monarch on whose dominions the sun never sets, it does appear as if geography ought to be a subject of vast importance instead of being one in many cases almost neglected. Sir R. Murchison, in presenting the medals at the recent meeting of the Royal Geographical Society, hoped that Eton, Harrow, Rugby and other great schnols might, in future years, send candidates, "for, without geography, a man cannot be said to be educated at all." Westminster School, it may be stated, to the disgrace of the rest, is the only public school represented in the competition, and has twice had honourable mention

The Royal Geographical Society has made a wise step in inaugurating this movement, which will give, it is to be hoped, a powerful stimulus to the popular study of geography. 'The learned societies are at present too much dissociated from the general education of the country. Science has so few votaries among the bulk of the population, that a knowledge of scientific facts, with anything like accuracy, or an acquaintance with scientific methods of working, is almost totally absent from the education of the majority. The scientific man is still to too many persons a species of magician, arriving at his information in occult ways, not to be penetrated by the ordinary observer.

Government is called upon from all sides to do this and that 
in the matter of education. But Government is slow to move, and is quite sure not to please everybody when it does. In the meantime let scientific societies, each anxiuus for the spread of knowledge on its own subject, take example by the Royal Geographical Society. Let prizes and honourable mentions be offered, let them be somewhat difficult of attainment, and let the distinction be matter of public award; and it will scon be seen that the scientific education of the country will have received a healthy and vigorous impulse, which will do much to spread the desired instruction through all classes of the nation.

J. A. Chessar

\section{ON THE PROGRESS OF BOTANY IN 1869} II.

WiTII regard to the succession of races which have undergone a complete specific change through successive geological periods, ve have not in plants, in as far as I am aware, any such cases of "true linear types or forms which are intermediate between others because they stand in a direct genetic relation to them," as Professor Huxley appears to have made out in favour of the nedigree of the horse in his last anniversary address to the Geological Society. And I may, in regard to plants, repeat with still greater emphasis his dictum, that "it is no easy matter to find clear and unmistakable evidence of filiation among fossil animals; for in order that such evidence should be quite satisfactory, it is necessary that we should be acquainted with all the most important features of the organisation of the animals which are supposed to be thus related, and not merely with the fragments upon which the genera and species of the palæontologist are so often based." The difficulty is much greater in the case of fossil plants ; for instead of bones, teeth, or shells, portions of internal or external skeletons, the parts preserved to us from the Tertiary period are generally those least indicative of structural organisation. Mr. Carruthers has recently (Geological Magazine, April and July 1869, and Fournal of the Geological Society, August 1869) adduced satisfactory evidence of the close affinity of Sigillaria and the allied genera of the coal-period with the living Lycopodiacea, formerly suggested by Dr. Hooker, but, as he informs me, no connecting links, no specimens indeed of the whole order, have as yet been found in any of the intermediate Cretaceous or Tertiary deposits. Among the latter the presence of numerous types, to which we may plausibly refer as to the ancestors of living races, is established upon unimpeachable data; but I have been unable to find that a single case of authentic pedigree, as successively altered from the Cretaceous through the abundant deposits of the Eocene and Miocene period to the living races, has been as yet as satisfactorily made out as that of the absolute identity of Taxodizm and others above mentioned, although I feel very little doubt that such a one will yet be traced when our palæontologists will have ceased to confound and reason alike upon the best proved facts and the wildest guesses. Our late distinguished foreign member, Professor Unger, whose loss we have had so recently to deplore, had indeed, shortly before his death, putlished, under the name of "Geologie der Europäischen Waldbäume, part x. Laubhölzer," no less than twelve tabular pedigrees of European forest races ; but it seems to me that in this, as in another of the same eminent palrontologist's papers to which I shall presently have to refer, his speculations have been deduced more freely from conjectures than from facts. There is no doubt that the presence of closely allied representatives of our Beeches, Birches, Alders, Oaks, Limes, \&c., in the Tertiary deposits of central and southern Europe is fully proved by inflorescences and fruits as well as leaves; but how can we establish the successive changes of character in a race when we have only the inflorescence of one period, the fruit of another, and the leaf of a third? I do not find a single case in which all three have been found in more than one stage, and by far the great miajority of these fossil species are established on the authority of detached leaves or fragments of leaves alone.

Now let us consider for a moment what place a leaf really holds in systematic botany. Would any experienced systematic botanist, however acute, on the sole examination of an unknown leaf, presume to determine, not only its natural order and genus, but its precise characters as an unpublished species? It is true that monographists have sometimes published new species founded on specimens without flower or fruit, which from collateral circumstances of habitat, collector's notes, general resemblance, \&c., they had good reason to believe really belonged to the genus they were occupied with; but then they had the advantage of ascertaining the general facies derived from insertion, relative position, presence or absence of stipular appendages, \&c. besides the data supplied by the branch itself. And with all these aids even the elder De Candolle, than whon no botanist was more sagacious in judging of a genus from general aspect, was proved to have been in several instances far wrong in the genus, and even order, to which he had attributed species described from leaf specimens only. Palæontologists, on the other hand, have, in the majority of these Tertiary deposits, had nothing to work upon but detached leaves or fragments of leaves, exhibiting only outward form, venation, and, to a certain degree, epidermal structure, all of which characters may be referred to that class which Professor Flower, in his introductory lecture at the Royal College of Surgeons in February last, has so aptly designated as adaptive, in contradistinction to essential and fundamental characters. They may, when taken in conjunction with relative individual abundance, assist in forming a general idea of the aspect of vegetation, and thus give some clue to certain physical conditions of the country; but they alone can afford no indication of genetic affinity, or consequently of origin or successive geographical distribution.

Lesquereux, in speaking of Cretaceous "species, or rather forms of leaves," observes in a note to his paper on Fossil Plants from Nebraska (Silliman's fournal, vol. xivi. July I868, p. I03), that " it is well understood that when the word specics is used in an examination of fossil plants, it is not taken in its precise sense, for indeed no species can be established from leaves or mere fragments of leaves. But as palæontologists have to recognise these forms described and figured, to compare them and use them for references, it is necessary to affix to them specific names, and therefore to consider them as species." But the investigators of the Tertiary floras of Central and Sonthern Europe have acquired the habit, not only of neglecting this distinction, and naming and treating these forms of leaves as species equivalent to those established on living plants, but of founding upon them theories which must fall to the ground if such specific determination proves inaccurate. Nothing can be more satisfactory than such determinations as that of Podogonizum for instance, which Professor Heer has succeeded in proving, by numerous specimens of leaves, fruits, and even flowers, some of them still attached to the branches, which I had myself the pleasure of inspecting last summer under the friendly guidance of the distinguished Professor himself. This genus of Cresalpineæ, from its evident affinity with Peltogyne, Tamarindus and others now scattered over the warmer regions of America and Africa, and more sparingly in Asia, tells a tale of much significance as to the physico-geographical relations of the Swiss Tertiary vegetation, confirmed as it is by some other equally, or almost equally, convincing examples. But the case appears to me to be far different from the theory so vividly expounded by Professor Unger in $\mathrm{r} 86 \mathrm{r}$ in his Address entitled "Neu Holland in Europa;" this generally admitted theory seems to me to be established on some such reasoning as this:- There are in the Tertiary deposits in Europe, and especially in the earlier ones, a number of leaves that look like those of Proteacere; Proteacer are a distinguishing feature in Australian vegetation ; ergo, European vegetation had in those times much of an Australian type derived from a direct land communication with that distant region.

This conviction that Proteacere, belonging to Australian genera, were numerous in Europe in Eocene times, is indeed regarded by palæontologists as one of the best proved of their facts. They enumerate nearly 100 Tertiary species, and most of them with such absolute confidence that it would seem the height of presumption for so inexperienced a palæontologist as myself to express any doubt on the subject. And yet, although the remains of the Tertiary vegetation are far too scanty to assert that Proteaceæ did not form part of it, I have no hesitation in stating that I do not believe that a single specimen has been found that a modern systematic botanist would admit to be Proteaceous, unless it had been received from a country where Proteacex were otherwise known to exist. And, on other grounds, I should be most unwilling to believe that any of the great Australian branches of the order ever reached Europe. As this is a statement requiring much more than mere assertion on my part, I shall beg to enter into some detail, commencing with a short summary of my grounds of disbelief in European Tertiary Proteaceæ, and then examining into the supposed evidences of their existence.

The analysis and detailed descriptions I have had to make 